\title{
A new species of Copionodon lacking a free orbital rim (Siluriformes: Trichomycteridae)
}

\author{
Mario de Pinna ${ }^{1}$, Rafael Burger ${ }^{2}$ and Angela Maria Zanata ${ }^{2}$
}

A new species of the copionodontine genus Copionodon is described from the upper reaches of a tributary to the rio Paraguaçu in the Diamantina Plateau, Bahia State, northeastern Brazil. This species represents the northernmost occurrence of the subfamily yet known. The new species can be readily recognized by its large eye without a free orbital rim. Other characters such as the entirely cartilaginous second hypobranchial, and the uniformly broad irregular midlateral dark band further diagnose the new taxon. Its particular combination of characters is superficially intermediate between Copionodon and Glaphyropoma. Detailed analysis, however, indicates that it forms a monophyletic group with species of Copionodon and therefore it should be included in that genus.

Key-words. Chapada Diamantina, Endemicity, New taxon, Rio Paraguaçu, Systematics, Taxonomy.

Uma nova espécie do gênero Copionodon, subfamília Copionodontinae, é descrita para o trecho superior de um tributário do Rio Paraguaçu na Chapada Diamantina, Estado da Bahia, nordeste do Brasil. Este registro representa a ocorrência mais ao norte de Copionodontinae até agora conhecido. A nova espécie pode ser facilmente reconhecida por ter olho grande sem margem orbital livre. Outras características como o segundo hipo-branquial inteiramente cartilaginoso e uma faixa escura lateral irregular de largura uniforme também servem para diagnosticar o táxon. A combinação particular de caracteres do novo táxon é superficialmente intermediária entre Copionodon e Glaphyropoma. Entretanto, uma análise mais detalhada indica que forma um grupo monofilético com Copionodon e portanto deve ser incluída neste gênero.

Palavras-chave. Chapada Diamantina, Endemicidade, Novo Táxon, Rio Paraguaçu, Sistemática, Taxonomia.

\section{Introduction}

One of the most unexpected discoveries in trichomycterid diversity in recent decades has been the subfamily Copionodontinae. The group was originally described to include the genus Copionodon, with two species, and Glaphyropoma, with one (de Pinna, 1992). Another species was subsequently described in the genus Copionodon (C. lianae Campanario, de Pinna, 2000) and another in Glaphyropoma (G. spinosum Bichuette et al., 2008). Copionodontine catfishes occur exclusively in the Chapada Diamantina, a vast and complex plateau composed of proterozoic terrain extending along the central portion of the State of Bahia, northeastern Brazil. The whole plateau covers 30.340 square $\mathrm{km}$, which is slightly smaller than the total area of Belgium. Much of the plateau is over $1000 \mathrm{~m}$ altitude, with some peaks reaching over $2000 \mathrm{~m}$. The Chapada Diamantina is drained by three different basins,
Rio Sao Francisco to the west, Rio de Contas to the south and Rio Paraguaçu to the east and north. So far, copionodontines have been found exclusively in rivers associated with the Paraguaçu. However, much of the Diamantina plateau is accessible only with difficulty and vast portions of it remain unexplored ichthyologically. Copionodontine catfishes are morphologically remarkably primitive compared to other trichomycterids, and lack many of the synapomorphies that were previously used to diagnose the entire family. They were originally described as sister group to all the rest of the family (de Pinna, 1992). That hypothesis was put into question when some putative synapomorphies were subsequently identified for copionodontines and the relict southeastern Brazilian Trichogenes longipinnis (de Pinna, 1998). Those early suspicions were confirmed on the occasion of the discovery of a second species of Trichogenes (de Pinna et al., 2010) and in results of other analyses based on both morphological and molecular evidence (Datovo,

${ }^{1}$ Museu de Zoologia da Universidade de São Paulo, Av. Nazaré, 481, 04263-000 São Paulo, SP, Brazil. pinna@ib.usp.br, @https:// orcid.org/0000-0003-1711-4816 (corresponding author).

${ }^{2}$ Instituto de Biologia, Universidade Federal da Bahia, Rua Barão de Geremoabo s/n, Ondina, 40170-115 Salvador, BA, Brazil. (AMZ) zanata.angela@gmail.com; (RB) rafaelburger1984@gmail.com 
Bockmann, 2010; Ochoa et al., 2017). It now seems certain that the Copionodontinae and Trichogeninae are sister groups, and that this clade, in turn, is the sister group to all other trichomycterids. Regardless of such issues, there is little doubt that the Copionodontinae form a monophyletic group diagnosed by several unambiguous synapomorphies, including a unique dentition composed of spatulate teeth not seen anywhere else in Trichomycteridae. A smaller set of characters also support the genera Copionodon and Glaphyropoma as monophyletic subunits.

Copionodontines occupy the upper reaches of streams on rocky beds, often with little or no water flow in the dry season. Some species (e.g., Copionodon orthiocarinatus) congregate on quiet pools, while others (e.g., C. pecten) show marked preference for high-energy sectors, usually anchored to the substrate against the strong current by means of their interopercular apparatus. While species of Copionodon are ubiquitous and easily seen elements in their habitat, those of Glaphyropoma are highly secretive and rarely seen or sampled. Incidentally, the only troglobitic copionodontine yet known is a member of the latter genus (Bichuette et al., 2008). Water in the upper reaches of the Chapada Diamantina is usually cool and almost always strongly tea-stained. Copionodontines are often the only fishes in their habitat, although one or two species of Characidae and Loricariidae may co-occur in some locations.

In this paper, we report on a new species of Copionodon from an outlying sector of the Diamantina plateau, representing the northermost record of the subfamily so far known. Its combination of characters offers an interesting mosaic of traits somewhat intermediate between Copionodon and Glaphyropoma. Such situation required a reevaluation of the characters used to diagnose the two genera, which we present along with a discussion of the evidence for the inclusion of the new species in the former genus.

\section{Material and methods}

Morphometric data were taken with digital calipers following the measurement definitions in de Pinna (1992). Osteological information was taken from specimens cleared and counterstained for bone and cartilage according to the method of Taylor, Van Dyke (1985). Osteological information from additional specimens, including vertebral counts, was taken from digital radiographs. Photographs were made with digital microphotographic system attached to an auto-focus Zeiss stereomicroscope. Acronyms for collections follow Sabaj (2016).

\section{Copionodon elysium, new species}

urn:1sid:zoobank.org:act:2D15386B-101C-43E0-910847076966C4CD

(Figs. 1-2; Tab. 1)

Holotype. MZUSP 120631, 45.0 mm SL, Brazil, State of Bahia, Chapada Diamantina, Município de Palmeiras, Vale do Capão near Morrão outcrop, Riacho Águas Claras, tributary of Rio Mucugezinho, itself tributary of Rio Santo Antonio, Rio Paraguaçu drainage, 12³1'19"S 41²8'52", M. de Pinna, V. Abrahão, V. Carvalho, A. Zanata, 6 Mar 2017.

Paratypes. All from same locality as holotype. MZUSP 121654, 52, 12.0-71.5 mm SL, collected with holotype; UFBA 8100, 1, $34.3 \mathrm{~mm}$ SL, R. Burger, 15 Jan 2016; UFBA 8163, 47 (1 c\&s), 10.3-46.5 mm SL, A. M. Zanata, R. Burger, P. Camelier, R. Freire, 26 Jun 2016; MZUSP 120630, 15 (3 c\&s), 21.7-59.7 mm SL and UFBA 8115, 6, 32.8-47.0 mm SL, R. Burger, 11 Apr 2016.

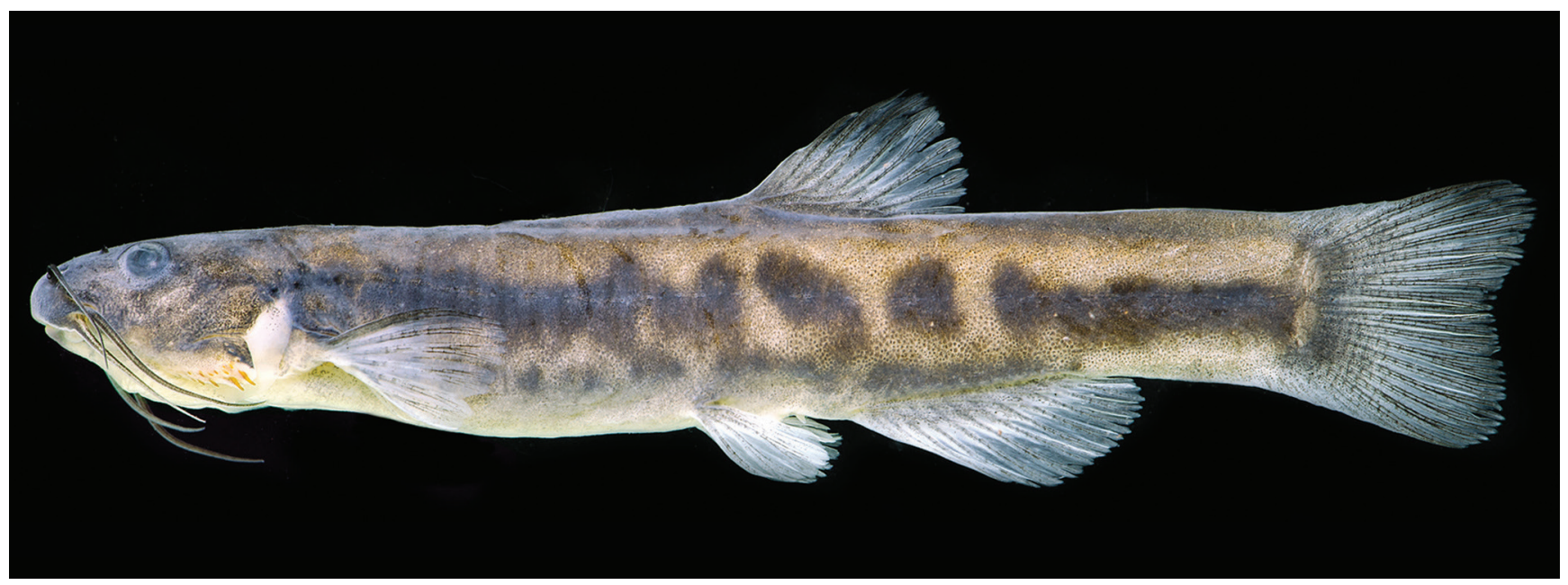

Fig. 1. Copionodon elysium, holotype, MZUSP 120631, 45.0 mm SL, Brazil, Bahia, Chapada Diamantina, Palmeiras, Rio Paraguaçu drainage. 


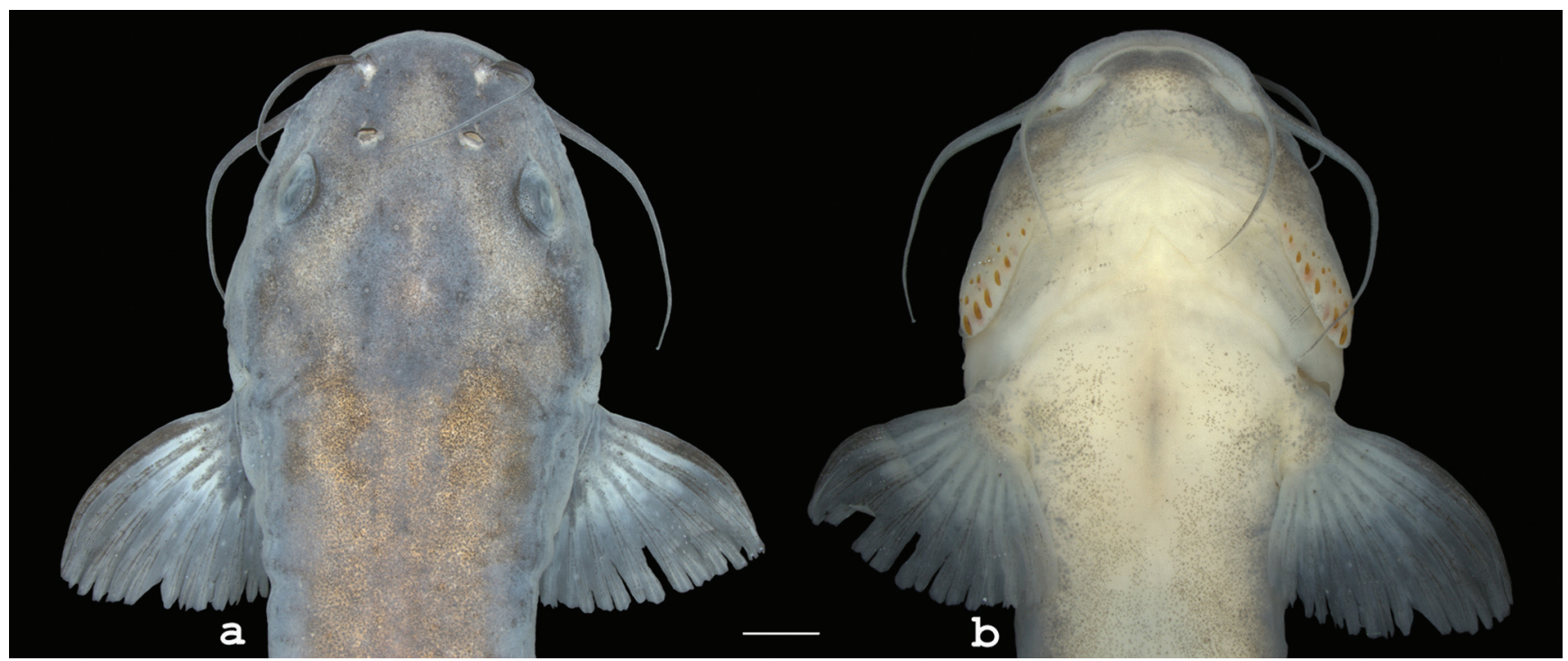

Fig. 2. Copionodon elysium, holotype, MZUSP 120631, Dorsal (a) and ventral (b) views of head. Scale bar $=2 \mathrm{~mm}$.

Table 1. Morphometric data for Copionodon elysium, new species. $\mathrm{N}=30 ; \mathrm{SD}=$ standard deviation.

\begin{tabular}{|c|c|c|c|c|}
\hline & Holotype & Range & Mean & $\mathrm{SD}$ \\
\hline Standard length in $\mathrm{mm}$ & 45.0 & $32.5-71.5$ & 44.5 & - \\
\hline \multicolumn{5}{|c|}{ Percents of standard length } \\
\hline Total length & 114.4 & $114.4-122.5$ & 118.9 & 1.8 \\
\hline Body depth & 17.3 & $13.5-18.4$ & 16.0 & 1.4 \\
\hline Predorsal length & 56.9 & $56.7-61.7$ & 59.0 & 1.2 \\
\hline Preanal length & 65.8 & $61.5-67.0$ & 65.1 & 1.3 \\
\hline Prepelvic length & 53.3 & $50.3-55.1$ & 52.4 & 1.2 \\
\hline Caudal-peduncle length & 19.8 & $16.5-21.0$ & 18.9 & 1.0 \\
\hline Caudal-peduncle depth & 14.9 & $11.3-14.9$ & 13.0 & 0.8 \\
\hline Dorsal-fin base length & 10.7 & $8.0-10.7$ & 9.5 & 0.7 \\
\hline Anal-fin base length & 16.4 & $14.4-18.4$ & 16.3 & 1.0 \\
\hline Head length & 22.2 & $21.3-23.7$ & 22.4 & 0.6 \\
\hline \multicolumn{5}{|c|}{ Percents of head length } \\
\hline Head width & 98.0 & $89.6-100.0$ & 92.9 & 3.4 \\
\hline Head depth & 54.0 & $46.1-54.6$ & 49.3 & 2.4 \\
\hline Snout length & 56.0 & $48.0-57.6$ & 52.5 & 2.3 \\
\hline Mouth width & 40.0 & $34.3-44.8$ & 36.3 & 2.2 \\
\hline Orbital diameter & 17.0 & $12.2-19.7$ & 16.5 & 1.9 \\
\hline Interorbital width & 50.0 & $45.1-53.0$ & 49.3 & 1.9 \\
\hline $\begin{array}{l}\text { Length of interopercular } \\
\text { patch of odontodes }\end{array}$ & 34.0 & $31.7-39.6$ & 35.2 & 2.0 \\
\hline
\end{tabular}

Diagnosis. Distinguished from all other copionodontine catfishes by the large eye without a free orbital rim (Figs. 1, 2; vs. large eyes and free orbital rim in Copionodon spp. or with small eyes but without a free orbital rim in Glaphyropoma spp.). Also, uniquely diagnosed in the subfamily by the second hypobranchial entirely cartilaginous (Fig. 3; vs. presence of a conical ossification cap in the anterolateral corner of the second hypobranchial in other copionodontines) and the reduced or vestigial adipose fin in adults, resulting in a dorsal profile of the caudal peduncle almost straight (Fig. 1; vs. caudal peduncle dorsally convex as a result of the well-developed adipose fin). Further distinguished from congeners by the thin upper and lower lips, with lower lip not flattened ventrally, continuous and not split in two halves by medial depression (Fig. 2b; vs. broader lips and presence of median constriction on lower lip), mouth inferior, located close to anterior margin of snout ( $v s$. mouth distinctly ventral, located posterior to anterior margin of snout), and by the posteriorly-positioned dorsal fin (predorsal distance $56.7-61.7 \%$ of SL vs. $46.0-55.0 \%$ of SL). The new species is also distinguished by its color pattern, with an uniformly broad midlateral dark (Fig. 1; vs. narrow dark band in $C$. pecten, somewhat broad and asymmetrical dark band in C. lianae, or absence of dark lateral band in remaining copionodontines). Copionodon elysium further differs from C. pecten by the smaller interopercular patch of odontodes, distant from lower lip anteriorly and not reaching opercular aperture (Fig. 2b; vs. interopercular patch of odontodes large, extending from near lower lip anteriorly to beyond pectoral-fin insertion posteriorly) and longer barbels, with maxillary barbel usually reaching pectoral-fin origin and rictal one extending beyond midlength of interopercular patch of odontodes ( $v s$. maxillary barbel reaching posterior $1 / 4$ of length of interopercular patch of odontodes and rictal reaching anterior $1 / 4$ of length of interopercular patch of odontodes). From the species of Glaphyropoma, the new taxon further differs by a series of characters, including the broad hypobranchial (Fig. 3; vs. slender), the caudal fin bilobed (Fig. 1; vs. truncate), the toothed portion on dentary not reaching the coronoid process (Fig. 4; vs. reaching coronoid process), and the presence of asymmetrical spatulate teeth in jaws (Fig. 4; vs. all teeth symmetrically spatulate). 


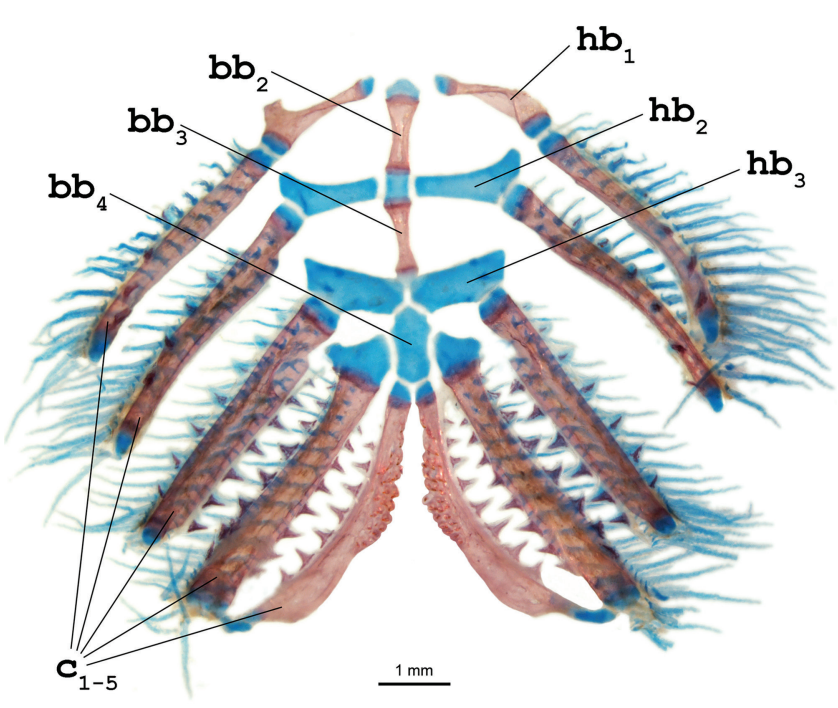

Fig. 3. Copionodon elysium, paratype, MZUSP 120630, lower branchial arches, dorsal view. Abbreviations: $\mathrm{bb}_{2-4}$, basibranchials 2 to $4 ; \mathrm{cc}_{1-5}$, ceratobranchials 1 to $5 ; \mathrm{hb}_{1-3}$, hypobranchials 1 to 3 .

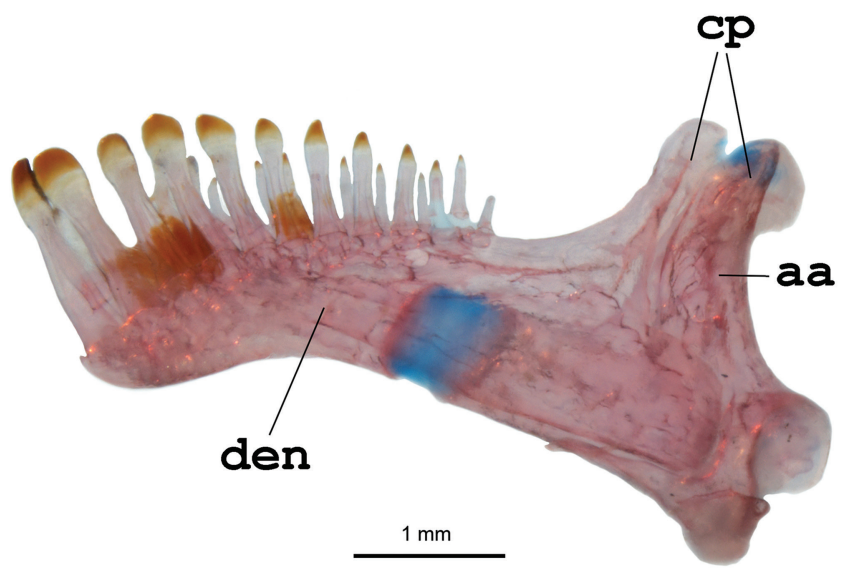

Fig. 4. Copionodon elysium, paratype, MZUSP 120630, lower jaw, left side, lateral view. Abbreviations: aa, anguloarticular; cp, coronoid process; den, dentary.

Description. Body elongate, trunk roughly round in crosssection, gradually more compressed posterior to dorsal fin. Caudal peduncle compressed, but less strongly than in congeners. Anterior part of body and head (Fig. 1), from snout to dorsal-fin origin, slightly convex. Posterior region of body, from endpoint of dorsal fin to caudal-fin origin, straight to slightly convex. Ventral profile straight along head and gular regions, nearly parallel to longitudinal axis of body; convex or slightly convex from that point to pelvic-fin origin and nearly straight or slightly concave from pelvic-fin base to caudal-fin base. Dorsal profile of adipose fin nearly straight; fin barely developed, somewhat more visible posterior to vertical through end of anal-fin base. Limit between adipose and caudal fins not welldefined.
Head (Fig. 2) slightly longer than wide or as long as wide in larger specimens, deep and not as depressed as in C. pecten. Mouth inferior, subterminal, located close to anterior margin of snout. Upper lip narrow in ventral view, not flattened ventrally. Ventral margin of upper lip partly continuous laterally with rictal barbel. Lower lip with about same thickness as upper lip; continuous, not divided in lateral halves by median constriction, only slightly concave mesially. Angle of mouth with fleshy outgrowth just posterior and adpressed to rictal barbel.

Dentary and premaxillary teeth somewhat similar to each other in shape and arrangement. Teeth gradually larger towards symphysis (Fig. 4). First row of teeth spatulate and darkly-pigmented distally in dentary and premaxilla, with spatulate portion in most teeth asymmetrical (Fig. 4). Asymmetric structure of teeth evident even in teeth only incipiently spatulate. Spatulate portion of teeth not overlapping in lower jaw (Fig. 4). Distal border of teeth straight. In both jaws, second row of teeth also slightly expanded distally; third row conical. Teeth on lower jaw distributed over anterior two thirds of ossification and not reaching coronoid process. Outer series of lower jaw with about 6-8 spatulate larger anterior teeth followed by 3-5 conical teeth.

Eye large, conspicuous, without free orbital rim and covered with skin (Fig. 2a). Rim of dark pigment along dorsal margin of eye (see below) creates false impression of free rim under cursory examination. Eye located at half of head length, closer to lateral border of head than to midline in dorsal view. Infraorbital latero-sensory canal complete, extending from sphenotic posteriorly to first infraorbital (lacrimal) anteriorly. Three infraorbital pores, one shortly posterior to vertical through posterior margin of eye, another ventral to ventralmost point of eye, and third approximately at vertical through posterior naris. Anterior naris surrounded by short anterolateral tube, continuous with nasal barbel. Posterior naris located between eyes and somewhat aligned longitudinally with anterior naris, not tubular and partly closed by two thin flaps of skin. Three pairs of flat barbels; barbels wide at base and gradually narrowing distally. Maxillary barbel reaching posterior margin of interopercle, or base of pectoral fin. Rictal barbel located ventral to maxillary, rictal extending beyond interopercular patch of odontodes and almost reaching posterior border of interopercle. Nasal barbel originating on posterolateral region of anterior naris, reaching up to opercular opening when completely and straightly extended. Barbels extension ontogenetically variable, longer in large juveniles and mature specimens. Interopercle with well-developed odontodes visible in ventral aspect of head (Fig. 2b). Interopercular patch of odontodes extending from vertical through posterior border of eye anteriorly and somewhat distant from border of opercular membrane posteriorly. Odontodes arranged in two series, medial series well-defined and lateral series somewhat disorganized; odontodes gradually larger 
posteriorly in all rows, those on inner row largest. Number of interopercular odontodes increasing with size: 5-6 odontodes in single row in small specimens (around 20.0 $\mathrm{mm} \mathrm{SL}$ ) and up to 21 odontodes distributed in two rows in larger specimens. Opercular region smooth, without opercular odontodes.

Pectoral fin large (notas large as in othercopionodontines), round in distal profile, its base immediately ventral to posterior tip of interopercle. Pectoral-fin rays i7i*(4), i8(4), i8i(10), i9(8), i9i(2), or i10(1). Pelvic fin with round distal profile, its origin anterior to vertical through dorsal-fin origin. Pelvic-fin rays ii4i(1), i4i(2), i5(2), i5i*(23), or i6(2), first ray (unbranched) shorter than others; when adpressed tip of pelvic-fin rays reaching or almost reaching anal-fin origin. Dorsal fin smaller than anal fin and similar in size to pectoral fin, its dorsal profile round. Dorsal-fin origin closer to base of caudal fin than to tip of snout. Dorsalfin rays ii5i*(4), ii6(3), ii6i(13), ii7(6), iii4i(1), or iii5i(1). Anal fin with base longer than that of dorsal, pectoral, and pelvic fins, its distal profile round. Anal-fin origin located aligned or shortly anterior to end of dorsal-fin base. Analfin rays ii9(3), ii10(1), iii9*(5), iii9i(2), iii10(11), iii10i(1), iv8i(1), iv9(1), or iv9i(2). Caudal fin bilobed, with i6/8i(1), $i 7 / 8 i^{*}(26)$, or $i 8 / 7 i(2)$ principal rays. Upper lobe slightly longer than lower lobe in some specimens. Dorsal procurrent rays 6(2), or 7(1) and ventral 8(1), or 9(2). Adipose poorly developed or vestigial in adults, lacking clear anterior and posterior limits and extending between vertical at base of posterior anal-fin rays and caudal-fin origin. Adipose fin larger and more well-defined in juveniles, clearly derived ontogenetically from larval fin-fold (Fig. 5).

Lateral line extending from posterior part of head to hypural plate, composed of interrupted series of short soft-tissue tubules lacking ossifications. Vertebrae 34(2), or 35(1) (exclusive of Weberian complex; ural complex counted as one), first dorsal-fin pterygiophore immediately posterior to neural spine of $12^{\text {th }}(10)$ or $13^{\text {th }}\left(9^{*}\right)$ vertebra, first anal-fin pterygiophore immediately posterior to neural spine of 14 th $(1), 15$ th $(9), 16$ th $\left(9^{*}\right)$, or 17th (1) vertebra. Pleural ribs 10 (1), 11 (1) or 12 (2). Branchiostegal rays 7 (3). Dorsal-fin pterygiophores 7(1), 8(1) or 9(1), including anterior rudimentary element when present. Anal-fin pterygionphores $12(3)$.

Coloration in alcohol. Sides of body with large partly coalescent black blotches (not coalescent in few specimens), forming broad midlateral dark band with approximately constant depth from rear of opercle to base of caudal fin (Fig. 1). Dorsal and ventral borders of band deeply sinuous, resulting in a zig-zag aspect in most the specimens. Lateral band symmetrical along midlateral line, with dark pigmentation somewhat equally distributed dorsally and ventrally to midalteral line. Additional, dark markings positioned dorsally to midlateral band, forming poorlydefined row on each side of middorsal line, restricted to dorsum anterior to dorsal fin origin. Middorsal line not outlined by dark pigment. Dark blotches below midlateral band small, usually barely fused forming inconspicuous narrow band variable in length, initiating in the rear of pectoral fin in some specimens or posterior to pelvic fin in others. Abdominal region white.

Overall color of head (Fig. 2a) similar to dorsal coloration of body or slightly darker, usually without dark blotches; specimens up to $30.0 \mathrm{~mm}$ SL may have small and inconspicuous dark markings. Mid-dorsal region of head, corresponding to central portion of skull roof, usually darker and more uniformly colored than surroundings; head dorsum homogeneously dark by concentration of minute melanophores in specimens up to $22.0 \mathrm{~mm}$ SL. Dorsal edge of eye outlined as thin dark line. Contour of laterosensory pores on head dorsum distinctly black. Small teardrop-shaped white area posterior to base of nasal barbel (Fig. 2a). Distal edge of skin flap on posterior naris very dark. Sides of head usually homogeneously tan, except in specimens up to $22.0 \mathrm{~mm} \mathrm{SL}$, with concentration of dark melanophores forming inconspicuous sinuous strip close to ventral margins of head and opercle. Ventral surface of head mostly white and with scattered minute melanophores along its contour. Anterior narrow border of lower lip and fleshy outgrowth at angle of mouth sparsely pigmented (Fig. 2b); upper lip heavily darkly-pigmented anteriorly, abruptly lighter posteriorly. Skin on region of interopercular patch of odontodes lacking melanophores. Nasal barbel uniformly dark. Maxillary barbel lighter than nasal barbel; dorsal surface darker than ventral. Rictal barbel with melanophores concentrated along its border and leaving central portion white, forming two lateral dark lines; ventral portion lighter and without dark lines. All fins with melanophores alongside individual rays and segment limits. Pelvic and anal fins somewhat lighter than remaining fins. Adipose fin scattered with melanophores, in pattern continuous to dorsal portion of body.

Coloration ontogenetically variable (Fig. 5). Specimens up to $17 \mathrm{~mm}$ SL strongly dark, nearly uniformly black, but with midlateral stripe faintly visible against dark background (Fig. 5a, b). Somewhat larger juvenile specimens with midlateral dark stripe continuous and very prominent (Fig. 5 c). Larger specimens with midlateral stripe less continuous and gradually masked by additional dark markings dorsal and ventral to it (Fig. 5d), approaching adult pattern (Figs. 1, 5e). Very large specimens (not shown in Fig. 5) more uniformly dark than smaller ones, with extra pigment partly masking midlateral stripe and other features.

Coloration in life. General color pattern similar to preserved specimens but uniformily darker, without dark blotches or with barely visible small ones. Mid-dorsal region of head with distinctly golden, roughly rectangular blotch. Lateral band not visible or barely visible on caudal peduncle. Fin-rays tan and intervening membranes yellowtinted. Distal portion of caudal peduncle and base of caudal fin light yellow. Ventral portion of body white. 


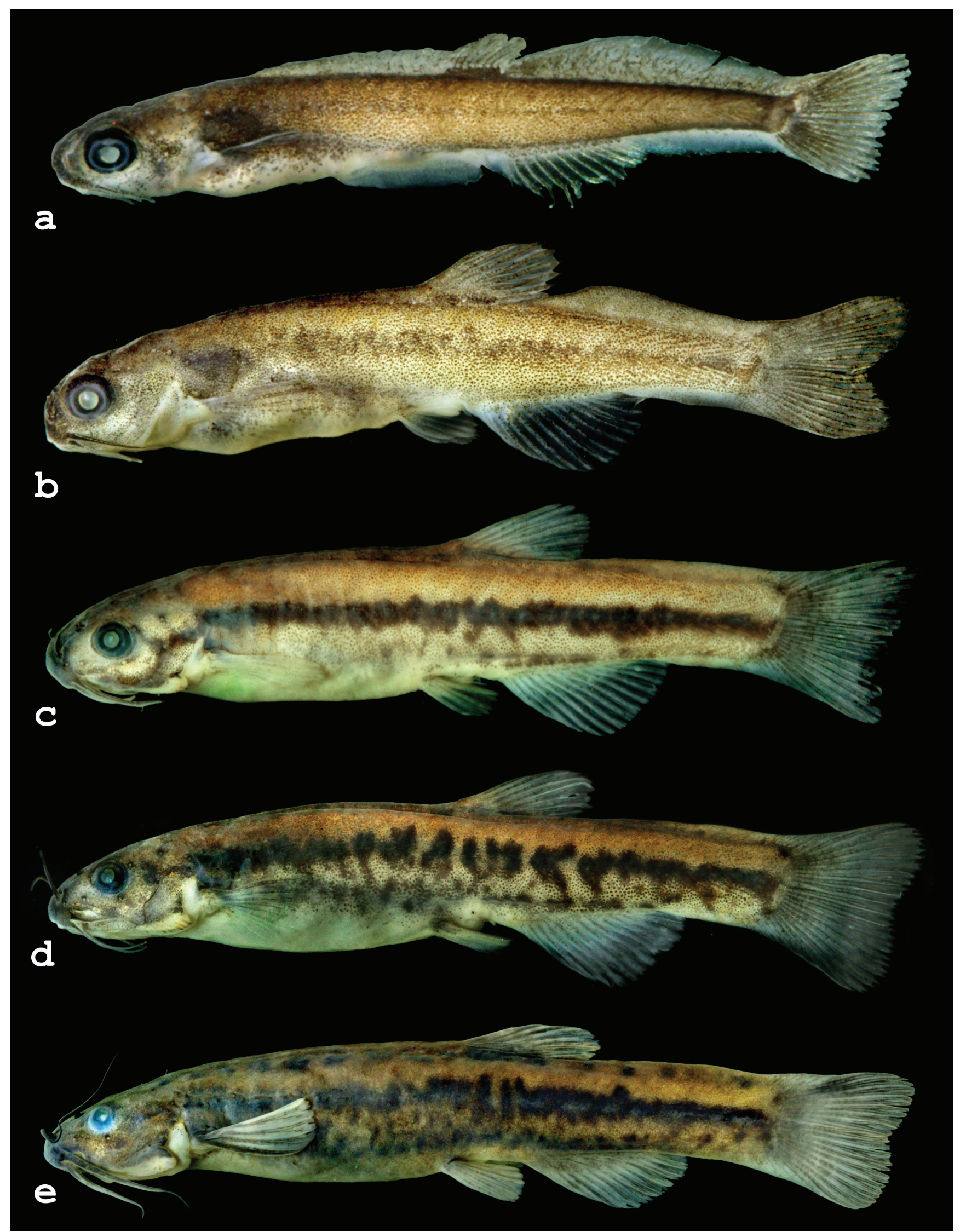

Fig. 5. Developmental stages of Copionodon elysium, UFBA 8163. (a) juvenile, $10.3 \mathrm{~mm}$ SL; (b) juvenile $14.5 \mathrm{~mm}$ SL; (c) juvenile, $26.5 \mathrm{~mm} \mathrm{SL}$; (d) juvenile, $31.5 \mathrm{~mm} \mathrm{SL}$; (e) adult female, $46.6 \mathrm{~mm}$ SL. 
Geographical distribution. Copionodon elysium is known exclusively from riacho Águas Claras, a stream of approximately $6 \mathrm{~km}$, tributary of rio Mucugezinho, itself a tributary of rio Santo Antonio, upper rio Paraguaçu basin, Chapada Diamantina, Bahia State, Brazil (Fig. 6).

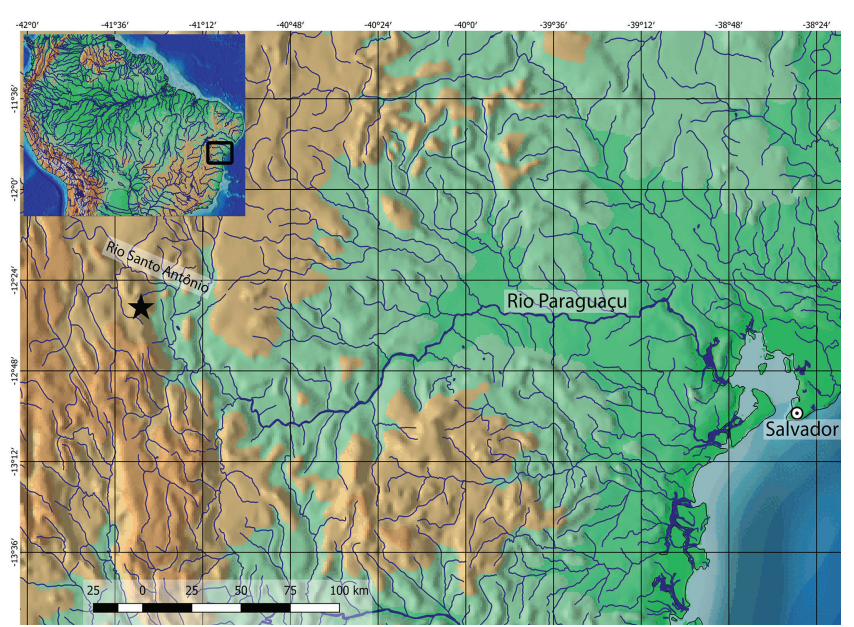

Fig. 6. Geographic distribution of Copionodon elysium.

Ecological notes. The Águas Claras stream is perennial and torrential in the rainy season. Its headwaters are around $1000 \mathrm{~m}$ above sea level and it runs on the western slopes of the Sincorá Range, partly within the Chapada Diamantina National Park. The population has a patchy distribution in the stream, with individuals concentrating in certain stretches and entirely absent in others. Copionodon elysium was sampled in slowflowing stretches over solid rock bottom or boulders, with riffles and shallow pools 10-30 centimeters deep and 1-3 meters wide (Fig. 7), with water transparent and tea-stained, though not to the same darkness as is typical in the Chapada Diamantina. Shallow pools have accumulations of plant debris along the margin. Marginal vegetation is typical "Campo Rupestre", an herbaceousshrub vegetation type that develops at elevations of about $900 \mathrm{~m}$ on sandstones and quartzite. Shrubs of Bonnetia stricta (Nees) Nees, Mart. (Bonnetiaceae) dominate the margins along the stretches sampled. The only other fish species collected with $C$. elysium was Astyanax sp.

The analysis of stomach contents of three specimens of C. elysium includes allochthonous and autochthonous items, composed mainly of aquatic insects (Trichoptera: larvae of Hydroptilidae and Hydropsychidae; Diptera: larvae of Simuliidae and Chironomidae; adult coleopterans; Plecoptera eggs), filamentous algae, and fragments of adult terrestrial insects (Hymenoptera: Formicidae), and numerous sand grains.

Considering the pristine condition of the type locality and its location inside an official preservation area, there are no evident threats to the survival of $C$. elysium, despite its narrowly endemic distribution and probably small population size.
Conservation status. Copionodon elysium is known exclusively from a stream ca. $6 \mathrm{~km}$ long, tributary of the Upper rio Paraguaçu basin, within the Chapada Diamantina Domain. The environment of the species has well oxygenated fast-running water running over rocky bottom. Because no specific threats have been detected, the species can be categorized as Least Concern (LC) according to IUCN criteria (IUCN, 2016), however, we emphasize the apparently narrowly endemic distribution of the species, which makes it (and most remaining copionodontines) dependent on the preservation of the delicate headwaters they inhabit.

Etymology. The specific epithet comes from the Greek elysium, in reference to the mythological Elysean Fields: a place or condition of ideal happiness; a state or place of perfect bliss. This alludes to the locality inhabited by the new species, a scenic pristine place (Fig. 7) shared with a single other fish species and no fish predators. A noun in apposition.

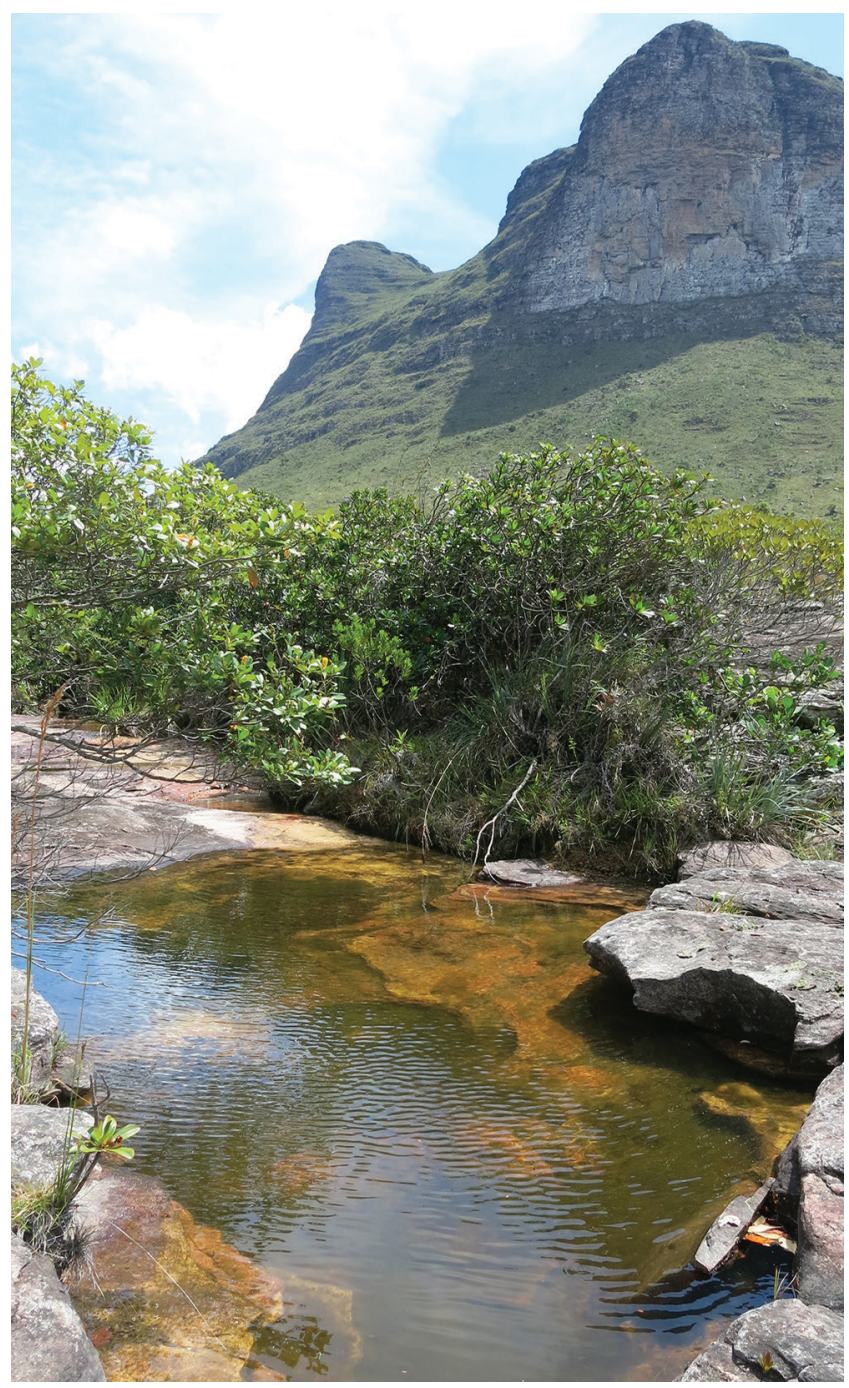

Fig. 7. Collection site of Copionodon elysium, Riacho Águas Claras, near Morrão, Bahia, Brazil. 


\section{Discussion}

The inclusion of the new species in the Copionodontinae is uncontroversial. Copionodon elysium shares all the diagnostic features for the subfamily originally proposed (de Pinna, 1992) and this alignment requires no further comment. The generic allocation, on the other hand, needs more detailed discussion. Within copionodontines, eyes without free orbital rim like those of $C$. elysium are seen only in species of Glaphyropoma ( $G$. rodriguesi and $G$. spinosum; cf. de Pinna, 1992; Bichuette et al., 2008) and this would suggest a possible alignment with that genus. This is somewhat ambiguously reinforced by the broad head of the new species, which in large specimens is as broad as long, like in species of Glaphyropoma. All species of Copionodon yet known, contrastingly, have a free orbital rim and a head which is longer than broad. Other characters, however, disagree with that placement. Copionodon elysium does not share the only unambiguous synapomorphy so far proposed for Glaphyropoma: the slender first hypobranchial (cf. de Pinna, 1992, fig. 6 and Bichuette et al., 2008, fig. 6). The new species clearly has a robust version of that bone as seen in all other species of Copionodon (Fig. 3). Furthermore, C. elysium has several of the synapomorphies proposed for Copionodon (de Pinna, 1992). The dentition in species of Copionodon include asymmetrically spatulate teeth (often overlapping one another as in C. pecten; see de Pinna, 1992, fig. 5; Zanata, Primitivo, 2013, fig. 4). In C. elysium the teeth do not overlap, but there are always a few clearly asymmetrical teeth (Fig. 4). Species of Glaphyropoma, in contrast, have all spatulate teeth with round symmetrical crowns. We consider the presence of any number of asymmetrical teeth as derived because immediate outgroups to Copionodontinae with modified tooth crowns (Species of Trichogenes and Nematogenys) have symmetrically bifurcated teeth (de Pinna, 1998).

The distribution of dentary teeth in Copionodon species does not reach the coronoid process and only a few (three or fewer) posterior teeth are conical (i.e, with no hint of spatulation), a configuration matched in C. elysium (Fig. 4). Lower jaw dentition in Glaphyropoma rodriguesi extends all the way to the coronoid process, with at least five laterallyplaced teeth conical. The situation in G. spinosum is closer to that in species of Copionodon and somewhat intermediate between the two genera. One of the previously proposed synapomorphies for Copionodon, the bilaterally-divided lower lip, is not present in C. elysium, which has a continuous lower lip like in Glaphyropoma. The latter condition, however, is plesiomorphic, and does not indicate a close relationship between the two taxa. Finally, the caudal fin in $C$. elysium is clearly bilobed as in all other Copionodon species and not truncate with round corners or slightly concave as in species of Glaphyropoma. Taking all evidence in consideration, the best generic assignment for the new species is in the genus Copionodon. At this time, however, its phylogenetic position within the genus is still indeterminate.
Comparative material examined. Brazil. Copionodon lianae: MZUSP 42470, 16 (2 c\&s), 11.3-44.5 mm SL, paratypes of Copionodon lianae Campanario, de Pinna, 2000. C. orthiocarinatus: MZUSP 42463, $37.7 \mathrm{~mm} \mathrm{SL}$, holotype of Copionodon orthiocarinatus de Pinna, 1992; UFBA 6033, 25 (1 c\&s), 25.2-56.8 mm SL. C. pecten: MZUSP 42462, 37 (5 c\&s), 31.4-62.2 mm SL, paratypes of Copionodon pecten de Pinna, 1992; UFBA 6034, 21, 27.9-66.7 SL; UFBA 8116, 12 (1 c\&s), 20.1-48.8 mm SL. Glaphyropoma rodriguesi: MZUSP 42466, 13 (3 c\&s), 28.8-45.4 mm SL, paratypes of Glaphyropoma rodriguesi de Pinna, 1992. G. spinosum: MZUSP 99742, 58.2 mm SL, holotypes of Glaphyropoma spinosum Bichuette, de Pinna, Trajano, 2008; MZUSP 99743, 4 (1 c\&s), 34.9-45.6 mm SL, paratypes of Glaphyropoma spinosum Bichuette, de Pinna, Trajano, 2008; UFBA 5298, 2 (1 c\&s), 43.1-44.4 mm SL.

\section{Acknowledgments}

We thank Vitor Abrahão, Vinicius Carvalho, Priscila Camelier and R. Freire for their help and companionship in fieldwork. Identification of insects found in gut contents was made by A. Calor. For help with photographs, we are grateful to Fernando Dagosta, Luis Peixoto and Vitor Abrahão. Flávio Bockmann kindly allowed use of x-ray facilities at his institution. Research funding is provided by FAPESP (\#2015/26804-4 to MDP), CNPq (\# 133917/2010 0 to AMZ and 308962/2013-3 to MDP) and CAPES (Protax $001 / 2015$ to $R B)$.

\section{Literature Cited}

Bichuette ME, de Pinna MCC, Trajano E. A new species of Glaphyropoma: the first subterranean copionodontine catfish and the first occurrence of opercular odontodes in the subfamily (Siluriformes: Trichomycteridae). Neotrop Ichthyol. 2008; 6(3):301-06.

Campanario CM, de Pinna MCC. A new species of the primitive trichomycterid subfamily Copionodontinae from northeastern Brazil (Teleostei: Trichomycteridae). Ichthyol Explor Freshw. 2000; 11(4):369-75.

Datovo A, Bockmann FA. Dorsolateral head muscles of the catfish families Nematogenyidae and Trichomycteridae (Siluriformes: Loricarioidei): comparative anatomy and phylogenetic analysis. Neotrop Ichthyol. 2010; 8(2):193-246.

International Union for Conservation of Nature (IUCN). Standards and Petitions Subcommittee. Guidelines for using the IUCN Red List Categories and Criteria. 2016; Version 12. Prepared by the Standards and Petitions Subcommittee. Available from: Available from: http://cmsdocs.s3.amazonaws.com/ RedListGuidelines.pdf

Ochoa LE, Roxo FF, DoNascimiento C, Sabaj MH, Datovo A, Alfaro M, Oliveira C. Multilocus analysis of the catfish family Trichomycteridae (Teleostei: Ostariophysi: Siluriformes) supporting a monophyletic Trichomycterinae. Mol Phylogenet Evol. 2017; 115:71-81. 
de Pinna MCC. A new subfamily of Trichomycteridae (Teleostei, Siluriformes), lower locarioid relationships and a discussion on the impact of additional taxa for phylogenetic analysis. Zool J Linn Soc. 1992; 106:175-229.

de Pinna MCC. Phylogenetic relationship of neotropical Siluriformes (Teleostei, Ostariophysi): historical overview and synthesis of hypotheses. In: Malabarba LR, Reis RE, Vari RP, Lucena ZMS, Lucena CAS, editors. Phylogeny and classification of Neotropical fishes. Porto Alegre: Edipucrs; 1998. p.279-330.

de Pinna MCC, Helmer JL, Britski HA, Nunes LR. A new species of Trichogenes from the rio Itapemirim drainage, southeastern Brazil, with comments on the monophyly of the genus (Siluriformes: Trichomycteridae). Neotrop Ichthyol. 2010; 8(4):707-17.

Sabaj MH. Standard symbolic codes for institutional resource collections in herpetology and ichthyology: an Online Reference. Version 6.5 (16 August 2016).Available from: http://www.asih.org/resources/standard-symbolic-codesinstitutional-resource-collections-herpetology-ichthyology
Taylor WR, Van Dyke GC. Revised procedures for staining and clearing small fishes and other vertebrates for bone cartilage. Cybium. 1985; 9(2):107-19.

Zanata AM, Primitivo C. Natural history of Copionodon pecten, an endemic trichomycterid catfish from Chapada Diamantina in northeastern Brazil. J Nat Hist. 2013; 48(3-4):203-28.

Submitted November 17, 2017 Accepted March 24, 2018 by Gloria Arratia 